Информация. Экспедиции ВНИРО

Результаты биологических исследований на шельфе Западной Камчатки летом 2021 г.

\author{
С.И. Моисеев ', А.В. Лысенкоㄱ, Т.Б. Морозов³, А.А. Матвеев³, Н.М. Блищак², С.А. Моисеева \\ ${ }^{1}$ Всероссийский научно-исследовательский институт рыбного хозяйства и океанографии (ФГБНУ «ВНИРО»), Окружной проезд, 19, г. Москва 105187 \\ ${ }^{2}$ Тихоокеанский филиал ФГБНУ «ВНИРО» («ТИНРО»), пер. Шевченко, 4, г. Владивосток, 690091 \\ ${ }^{3}$ Камчатский филиал ФГБНУ «ВНИРО» («КамчатНИРО»), ул. Набережная, 18, г. Петропавловск-Камчатский, 683000 \\ ${ }^{4}$ Институт биофизики клетки (ФГБУН «ИБК РАН»), Институтская, 3, г. Пущино, Московская область, 142290 \\ E-mail:moiseev@vniro.ru
}

\begin{abstract}
Целью проведённых исследований является оценка запаса и биологического состояния промысловых видов беспозвоночных и других гидробионтов на шельфе Западной Камчатки. Приводятся результаты, способствующие охарактеризовать современное состояние промысловых популяций донных и придонных гидробионтов, обитающих на глубинах 14-303 м.

Материал и методы - традиционные для рыбохозяйственных исследований, данные получены в июне-июле 2021 г. во время ежегодной донной учётной траловой съёмки. В районе работ базовыми объектами изучения были камчатский краб (Paralithodes camtschaticus) и краб-стригун Бэрда (Chionoecetes bairdi).

Новые данные, полученные по результатам прямого учёта, показали следующее: 1) в Камчатско-Курильской подзоне запас $P$. camtschaticus находится в неопределённом состоянии, близком к неудовлетворительному, а численность C. bairdi достигла наибольших значений за последнее десятилетие; 2) в Западно-Камчатской подзоне состояние запаса P. camtschaticus было удовлетворительным, за исключением южной части подзоны, где отмечены низкие уловы этого вида; 3) биологическое состояние и запас других промысловых беспозвоночных и рыб донного комплекса было удовлетворительным.

Практическая значимость представленных результатов исследований состоит в обеспечении ежегодных прогностических материалов по общим допустимым уловам донных промысловых видов гидробионтов для районов шельфа Западной Камчатки.
\end{abstract}

Ключевые слова: донная траловая съёмка, запас, распределение, биология, Paralithodes camtschaticus, Chionoecetes bairdi, промысловые беспозвоночные и рыбы.

\title{
Results of biological research on the shelf of Western Kamchatka in the summer of 2021
}

Sergey I. Moiseev', Aleksandr V. Lysenko², Taras B. Morozov³, Andrey A. Matveev³,

Nikita M. Blishehak2, Svetlana A. Moiseeva ${ }^{4}$

${ }^{1}$ Russian Federal Research Institute of Fisheries and Oceanography («VNIRO»), 19, Okruzhnoy proezd, Moscow, 105187, Russia

2Pacific branch of VNIRO («TINRO»), 4, per. Shevchenko, Vladivostok, 690091, Russia

${ }^{3}$ Kamchatka Branch of VNIRO («KamchatNIRO»), 18, Naberejnaya Str., Petropavlovsk-Kamchatsky, 683000, Russia

${ }^{4}$ Institute of Cell Biophysics RAS («ICB RAS»), 3, Institutskaya str., Pushchino, Moscow reg., 142290, Russia

The purpose of the research is to assess the stock and biological condition of commercial invertebrate species and other aquatic organisms on the shelf of Western Kamchatka. The results contributing to characterize the current state of commercial populations of bottom and bottom hydrobionts living at depths of $14-303 \mathrm{~m}$ are presented.

Data collection methods are traditional for fisheries research, the data were obtained during the annual bottom trawl survey in June-July 2021. In the area of work, the basic objects of study were the red king crab (Paralithodes camtschaticus) and of the southern Tanner crab (Chionoecetes bairdi).

New knowledge gained as a result of direct accounting showed the following: 1) in the Kamchatka-Kuril subzone, the stock of $P$. camtschaticus is in an uncertain state, close to unsatisfactory, and the number of $C$. bairdi has reached the highest values over the past decade; 2 ) in the West Kamchatka subzone, the stock of $P$. camtschaticus was satisfactory, with the exception of the southern part of the subzone, where low catches of this species were noted; 3 ) the biological condition and stock of other commercial invertebrates and fish of the bottom complex was satisfactory.

The practical significance of the presented research results is to provide annual prognostic materials on the total allowable catches of bottom commercial species of hydrobionts for the shelf areas of Western Kamchatka.

Keywords: bottom trawl survey, stock, distribution, biology, red king crab Paralithodes camtschaticus, bairdi crab Chionoecetes bairdi, commercial invertebrates and fish. 
В 2021 г. реализована учётная донная траловая съёмка с целью оценки запаса и биологического состояния промысловых беспозвоночных и других гидробионтов, обитающих на шельфе Западной Камчатки. Траления выполнялись на научно-исследовательском судне (НИС) «Дмитрий Песков», принадлежащем «БИФ ВНИРО» (филиал ФГБНУ «ВНИРО»). Самплер - донный трал ДТ/ТВ 27,1/24,4 с мелкоячейной вставкой в кутце и мягким грунтропом с грузами из якорной цепи весом 214 кг. Горизонтальное раскрытие трала 16 м, вертикальное 3,5-4 м, продолжительность траления 25-30 минут, средняя скорость 2,6 узла. Научно-исследовательские работы проходили в Камчатско-Курильской подзоне 1-22 июня на глубинах 14-303 м и в Западно-Камчатской с 22 июня по 5 июля на 14-200 м. В уловах отмечено 97 беспозвоночных животных и 104 вида рыб. Для основных видов рассмотрены биология, пространственное распределение и дана оценка мгновенной численности (запаса). Биологическое состояние гидробионтов изучали по общепринятым методам рыбохозяйственных исследований [Родин и др., 1979; Бизиков и др., 2006; Моисеев и др., 2018]. Для сбора данных по температуре $\left(\mathrm{T}^{\circ} \mathrm{C}\right)$ воды в придонных слоях использовали термодатчики «Термохрон», которые крепили к верхней подборе трала. В период НИР наиболее вариабельной $\mathrm{T}^{\circ} \mathrm{C}$ воды была у дна на 14-30 м. В начале июня $\mathrm{T}^{\circ} \mathrm{C}$ была около $4{ }^{\circ} \mathrm{C}$ изред- ка достигая $6{ }^{\circ} \mathrm{C}$, а к началу июля $\mathrm{T}^{\circ} \mathrm{C}$ была $4-8{ }^{\circ} \mathrm{C}$. В северной части района НИР на 75-130 м отмечены придонные линзы с холодными водами от $-0,2$ до $+0,5{ }^{\circ} \mathrm{C}$ (рис. 1).

В районе НИР ценными объектами для рыбной отрасли являются - краб камчатский Paralithodes camtschaticus (Tilesius, 1815), краб-стригун Бэрда Chionoecetes bairdi Rathbun, 1924 и гидробионты, для которых устанавливается общий допустимый улов. При описании биологического состояния крабов были рассмотрены функциональные группы, размерный состав, межлиночное состояние карапакса и развитие икры у самок.

Краб камчатский. В Камчатско-Курильской подзоне краб встречался штучно на 14-100 м, иногда до 150 м. Улов составил 333 экз., из них 124 экз. пойманы однажды на севере подзоны на 45 м. Биологическое состояние P. camtschaticus (табл. 1) было характерным для летнего сезона, большинство крабов нагуливались после сезонных миграций, линьки и/или нерестового спаривания, а меньшая часть готовилась к линьке.

В Западно-Камчатской подзоне $P$. camtschaticus наблюдался на 14-90 м, иногда до 150 м. В улове преобладали самцы, составляя $67 \%$. Биологическое состояние этого вида было не характерно для лета, а больше соответствовало переходному периоду вес-

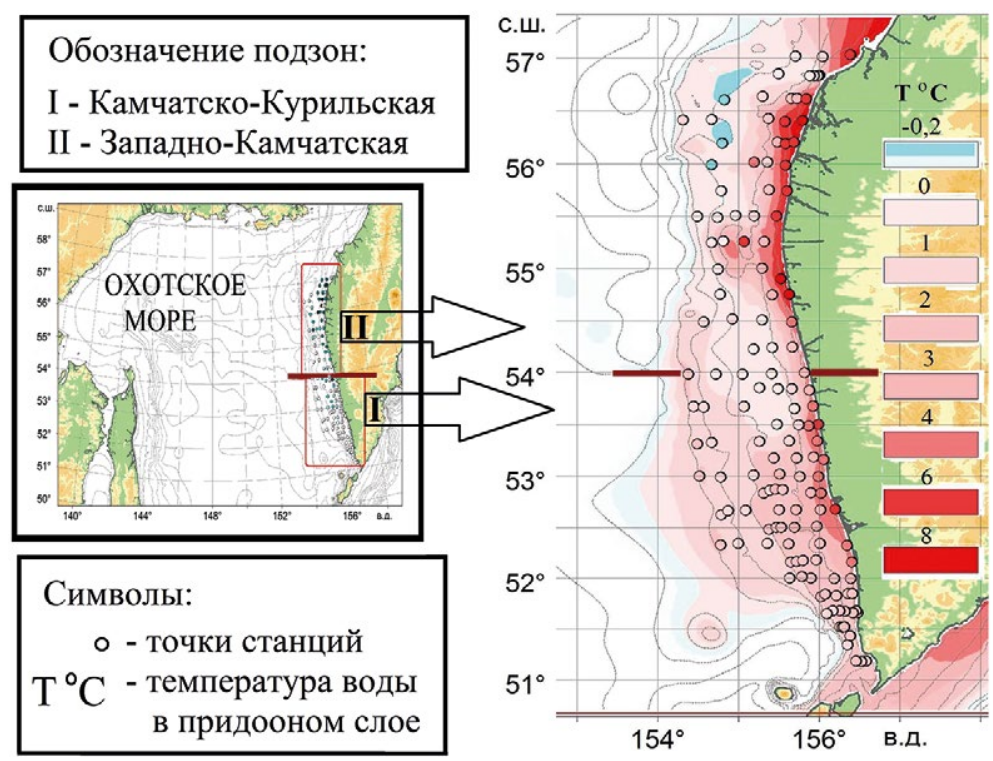

Рис. 1. Схема района проведения донной траловой съёмки на шельфе Западной Камчатки летом 2021 г. и распределение температуры воды у грунта в период НИР. Район I - Камчатско-Курильская подзона; район II - Западно-Камчатская подзона

Fig. 1. The scheme of the bottom trawl survey area on the shelf of Western Kamchatka in the summer of 2021 and the distribution of water temperature at the bottom during the research period. District I - Kamchatka-Kuril subzone; District II West Kamchatka subzone 
Таблица 1. Биологические характеристики основных промысловых видов крабов

Table 1. Biological characteristics of the main commercial crab species

\begin{tabular}{|c|c|c|c|c|c|c|c|c|c|c|c|c|c|}
\hline \multirow{2}{*}{\multicolumn{2}{|c|}{ Показатели }} & \multicolumn{4}{|c|}{ P. camtschaticus } & \multicolumn{4}{|c|}{ C. bairdi } & \multirow{2}{*}{\multicolumn{2}{|c|}{$\begin{array}{c}\text { P. platypus } \\
\text { Район II }\end{array}$}} & \multirow{2}{*}{\multicolumn{2}{|c|}{$\begin{array}{c}\text { C. opilio } \\
\text { Район I+II }\end{array}$}} \\
\hline & & \multicolumn{2}{|c|}{ Район I } & \multicolumn{2}{|c|}{ Район II } & \multicolumn{2}{|c|}{ Район I } & \multicolumn{2}{|c|}{ Район II } & & & & \\
\hline \multicolumn{2}{|c|}{ Число ふぇふ/ 우 1} & \multicolumn{2}{|c|}{$291 / 42$} & \multicolumn{2}{|c|}{$2667-885$} & \multicolumn{2}{|c|}{$3986-2523$} & \multicolumn{2}{|c|}{$399-275$} & \multicolumn{2}{|c|}{$492-182$} & \multicolumn{2}{|c|}{$1253-753$} \\
\hline \multicolumn{2}{|c|}{ ठठ ШK min-max, мм } & \multicolumn{2}{|c|}{$76-227$} & \multicolumn{2}{|c|}{$52-217$} & \multicolumn{2}{|c|}{$13-176$} & \multicolumn{2}{|c|}{$64-154$} & \multicolumn{2}{|c|}{$72-193$} & \multicolumn{2}{|c|}{$5,7-163$} \\
\hline \multirow{2}{*}{\multicolumn{2}{|c|}{$\begin{array}{l}\text { えふ̃ мода / } \\
\text { средняя ШК, мм }\end{array}$}} & \multicolumn{2}{|c|}{$181-190$} & \multicolumn{2}{|c|}{$171-180$} & \multicolumn{2}{|c|}{$126-130$} & \multicolumn{2}{|c|}{$96-110$} & \multicolumn{2}{|c|}{$161-170$} & \multicolumn{2}{|c|}{$56-60$} \\
\hline & & \multicolumn{2}{|c|}{180,7} & \multicolumn{2}{|c|}{163,5} & & & & 4,8 & & 0,2 & 65 & \\
\hline \% промысловы & bx $\hat{\sigma} /$ & & $2 \%$ & & & & $7 \%$ & & $1 \%$ & & $1 \%$ & 15 , & \\
\hline их средняя ШК & $\mathrm{K}, \mathrm{MM}$ & & 4,9 & & & & & & 9,4 & & 7,2 & 11 & \\
\hline 우우 min-max Ш & لК, MM & 46 & 163 & 71 & 160 & 27 & 118 & 70 & 112 & & 124 & $6,5-$ & 04 \\
\hline 우 мода / & & 141 & 150 & 111 & 120 & & 95 & & -95 & 10 & -110 & 56 & \\
\hline средняя ШК, мІ & & & 6,6 & & & & & & 1,9 & & 5,0 & $\partial^{4}$ & \\
\hline Стадии & би/ив/иц & $28,6 / 9$ & $5 / 61,9$ & $3,2 / 6$ & $4 / 78,5$ & $15,7 / 2$ & $6 / 68,4$ & $12,0 / 3$ & $3 / 58,2$ & $0,5 / 2$ & $3 / 60,4$ & $65,5 / 13$ & $1 / 20,5$ \\
\hline икры & б/иг/лв/ял & & $1-/-$ & $11,6 / 0$ & $1 /-/ 0,1$ & $-/ 11,1$ & $2,1 / 0,1$ & $-/ 25$ & $8 / 0,4 /$ & 18,1 & $0,5 /-/-$ & $0,9 /$ & $1-1-$ \\
\hline & o웅 & $\hat{\partial}$ & 우우 & $\hat{\partial}$ & 우우 & $\hat{\partial}$ & 우우 & $\hat{\partial}$ & 우우 & $\hat{\partial}$ & 우우 & $\hat{\partial}$ & 우우 \\
\hline & 1 & - & - & 0,0 & 1,9 & 0,2 & - & - & - & - & - & 1,1 & 1,7 \\
\hline Межлиночная & 2 & 0,3 & 61,9 & 0,9 & 30,4 & 8,4 & 0,6 & 6,0 & 5,3 & 2,6 & 3,8 & 3,8 & 5,0 \\
\hline стадия (внеш- & 3.0 & 8,2 & 38,1 & 10,4 & 27,8 & 22,0 & 2,4 & 34,3 & 15,5 & 35,0 & 22,3 & 9,7 & 2,5 \\
\hline $\begin{array}{l}\text { нее состояние } \\
\text { карапакса), \% }\end{array}$ & 3.1 & 77,7 & - & 41,7 & 33,6 & 46,2 & 68,9 & 35,1 & 62,1 & 38,2 & 53,5 & 79,2 & 87,4 \\
\hline & 3.2 & 13,1 & - & 41,1 & 4,1 & 22,9 & 28,1 & 24,6 & 17,0 & 19,7 & 20,4 & 6,0 & 3,4 \\
\hline & 4 & 0,7 & - & 5,9 & 2,2 & 0,4 & - & - & - & 4,5 & - & 0,2 & - \\
\hline
\end{tabular}

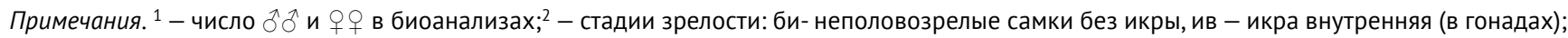
иц - икра цветная, новая оранжевая (ио), фиолетовая (иф) или другого цвета, нг - стадия начального глазка, икра бурая (иб), ип - икра поздняя, лв - личинки выпущены, ял - яловая.

на-лето. Основная доля самцов была в постлиночном и предлиночном состоянии, а у самок завершался нерест, более $2 / 3$ были с новой недавно отложенной икрой (табл. 1).

В период НИР у самцов камчатского краба наполнение конечностей мышечной тканью (НКМТ) и содержание белка в гемолимфе (СБГ) были с большим разбросом значений (табл. 2). У самок физиологические параметры также колебались НКМТ 30-85\%, СБГ 3,3-8,2 г/100 мл, а в среднем 68\% и 6,3 единицы, соответственно. Невысокие средние значения параме- тров указывали на низкий темп нагула и синтез мышечной массы у крабов в период НИР.

В 2021 г. распределение плотности P. camtschaticus на шельфе Западной Камчатки было мозаичным. В районах южнее $55^{\circ} 45^{\prime}$ с.ш. крабы встречались реже, чем в предыдущие годы. Для этих районов промысла состояние запаса неопределённое, близкое к неудовлетворительному, а севернее $55^{\circ} 45^{\prime}$ с.ш. удовлетворительное. На современном этапе у $P$. camtschaticus наблюдается низкая миграционная активность из северных районов в южные. На участке $56^{\circ} 15^{\prime}-56^{\circ} 45^{\prime}$ с.ш. в области проявления холодных линз у дна на

Таблица 2. Физиологические и биохимические параметры самцов крабов в районе НИР

Table 2. Physiological and biochemical parameters of male crabs in the research area

\begin{tabular}{lcccc}
\hline \multicolumn{1}{c}{ Параметр } & Стадия & P. camtschaticus & C. bairdi & P. platypus \\
\hline \multirow{3}{*}{ НКМТ, \% } & $2-3.0$ & $30-60 / 50$ & $40-71 / 61$ & $40-65 / 50$ \\
\cline { 2 - 5 } & $3.1-3.2$ & $55-90 / 77$ & $65-100 / 81$ & $75-95 / 86$ \\
\cline { 2 - 4 } & 4 & $60-80 / 70$ & $40-70 / 58$ & $70-80 / 75$ \\
\hline \multirow{2}{*}{ СБГ, г/100 мл } & $2-3.0$ & $2,0-3,4 / 2,9$ & $2,3-3,1 / 2,7$ & $2,3-3,7 / 3,1$ \\
\cline { 2 - 5 } & $3.1-3.2$ & $3,1-6,1 / 4,5$ & $3,2-6,3 / 4,4$ & $3,3-6,8 / 5,3$ \\
\hline & 4 & $3,2-4,4 / 5,3$ & $3,0-3,6 / 3,2$ & $3,9-4,6 / 4,2$ \\
\hline
\end{tabular}



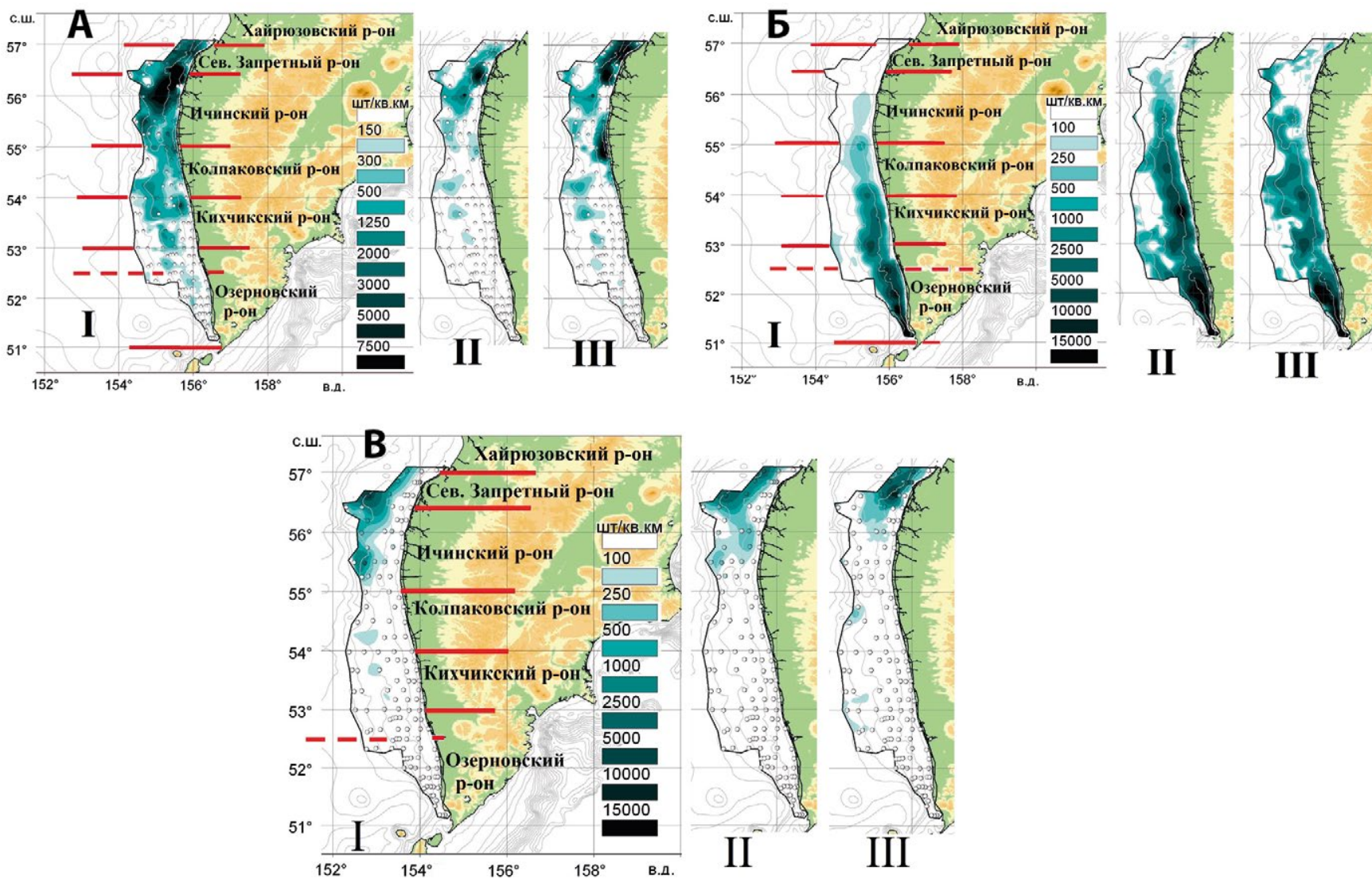

Рис. 2. Пространственное распределение крабов P. camtschaticus (A), C. bairdi (Б) и P. platypus (В) в районе шельфа Западной Камчатки летом 2021 г. Обозначения: I - самцы с промысловой ШК; II - непромысловые самцы; III - самки

Fig. 2. Spatial distribution of crabs P. camtschaticus (A), C. bairdi (B) and P. platypus (C) in the shelf area of Western Kamchatka in the summer of 2021. Designations: I - commercial males; II - non - commercial males; III - females

Таблица 3. Оценка мгновенного запаса (млн экз.) промысловых беспозвоночных

Table 3. Estimation of the instantaneous stock (million copies) of commercial invertebrates

\begin{tabular}{|c|c|c|c|c|c|c|c|c|c|}
\hline \multirow{2}{*}{$\begin{array}{c}\text { Промысловые беспозво- } \\
\text { ночные и }\end{array}$} & \multicolumn{3}{|c|}{$\begin{array}{c}\text { Камчатско-Курильская подзона, } \\
\text { S=26300 км² }\end{array}$} & \multicolumn{3}{|c|}{$\begin{array}{c}\text { Западно-Камчатская подзона, } \\
\text { S=25400 км² }\end{array}$} & \multicolumn{3}{|c|}{$\begin{array}{l}\text { Всего в районе НИР } \\
S=51700 \text { кM }^{2}\end{array}$} \\
\hline & пром* ${ }^{*}$ & молодь & самки & пром* & молодь & самки & пром* & молодь & самки \\
\hline Камчатский краб & 6,8 & 2,9 & 1,7 & 63,23 & 35,55 & 28,97 & 70,0 & 38,5 & 30,7 \\
\hline Синий краб & 0,44 & 0 & 0,16 & 8,7 & 1,6 & 1,9 & 9,14 & 1,6 & 2,06 \\
\hline Краб-стригун опилио & 4,191 & 49,054 & 30,550 & 0,353 & 7,157 & 7,805 & 4,544 & 56,211 & 38,355 \\
\hline Краб-стригун Бэрда & 62,8 & 122,6 & 119,8 & 3,487 & 21,974 & 18,174 & 66,281 & 144,549 & 138,002 \\
\hline $\begin{array}{l}\text { Четырехугольный } \\
\text { волосатый краб }\end{array}$ & 1,9 & 1,65 & 0,26 & 0,4 & 1,27 & 0,39 & 2,3 & 2,92 & 0,65 \\
\hline Креветка северная & $7,65^{* *}$ & & & & & & $7,65^{* *}$ & & \\
\hline Кукумария & $208,7^{* *}$ & & & $84^{* *}$ & & & $292,7^{* *}$ & & \\
\hline
\end{tabular}

Примечание: * - промысловая мера для ракообразных; ** - выполнена оценка биомассы в тыс. т

100-130 м в уловах отсутствовали молодые самцы и самки, и наоборот, наблюдалось увеличение численности у всех групп крабов на меньших глубинах, расположенных восточнее холодных линз (см. рис. 1-2A). Оценка запаса дана для трёх функциональных групп камчатского краба (табл. 3).
Краб-стригун Бэрда. В Камчатско-Курильской подзоне этот вид встречался на 14-303 м. Различные функциональные группы формировали скопления на 40-80 м, как в районе промысла южнее $52^{\circ} 30^{\prime}$ с.ш., так и севернее этой границы, иногда небольшие скопления были до 120-150 м (рис. 2 Б). Размерный со- 
став самцов был с двумя модами 96-110 мм (20\%) и 126-130 мм (8\%). У самок завершался нерест, $70 \%$ были с новой икрой, а $16 \%$ неполовозрелыми (табл. 1). Высокая доля встречаемости самок обеспечивает хорошие перспективы для воспроизводства $C$. bairdi в ближайшие годы. Прохождение терминальной линьки находили отдельно для каждого самца по коэффициенту морфометрической половозрелости [Моисеев и др., 2018]. Среди самцов с ШК $\geqslant 120$ мм широкопалые самцы (ШПС) составляли $90 \%$, а узкопалые самцы (УПС) 10\%. Среди непромысловых самцов с ШК <120 мм ШПС составляли 36,4\%, а УПС 63,6\%. В Западно-Камчатская подзоне C. bairdi чаще встречался южнее $55^{\circ} 00^{\prime}$ с.ш. на 40-75 м иногда до 120 м. Биологическое состояние было сходным с таковым из южных районов, но в уловах доминировали самцы с ШК <120 мм - 83,9\% (табл. 1). Среди самцов с ШК $\geqslant 120$ мм ШПС составляли 89,5\%, а УПС соответственно $10,5 \%$. У самцов с ШК <120 мм соотношение между ШПС и УПС практически было равным, ШПС составляли 49,1и 50,9\%, соответственно УПС. Летом у самцов C. bairdi значения НКМТ и СБГ имели большой разброс, а не высокие средние значения (табл. 2) указывали на низкий синтез мышечной массы. Колебания физиологических параметров самок были меньше, чем у самцов - НКМТ 70-95\%, СБГ 3,3-8,2 г/100 мл, в среднем $87 \%$ и 5,5 единицы, соответственно. Оценка запаса C. bairdi находится на историческом максимуме (табл. 3).

Краб синий P. platypus (Brandt, 1850). Чаще встречался севернее $55^{\circ} 30^{\prime}$ с.ш. (рис. 2В). Биологическое состояние P. platypus соответствовало летнему сезону (табл. 1). У самок физиологические параметры имели значительный разброс НКМТ 40-95\%, СБГ 2,7-7,1 г/100 мл, в среднем $75 \%$ и 6,0 единицы, соответственно. У самцов вариабельность НКМТ и СБГ была менее выражена (табл. 2), что указывало на интенсивность нагула и миграционную активность. В районе НИР величина запаса P. platypus удовлетворительная (табл. 3).

Краб-стригун опилио Chionoecetes opilio (Fabricius, 1788). Встречался по всему шельфу НИР на 90-303 м с максимумом на 180-230 м. В уловах у обоих полов доминировали особи с ШК 26-70 мм и с двумя модами 41-45 и 56-65 мм. Среди самцов с ШК $\geqslant 100$ мм ШПС составляли всего 9\% от всех самцов, а УПС только $5 \%$. У самцов с ШК <100 мм ШПС составляли $16 \%$, а УПС $70 \%$.

Четырёхугольный волосатый краб Erimacrus isenbeckii (Brandt, 1848). Отмечался на 14-90 м, но преобладал на 30-45 м. Из 291 экз. самцов было 89\%, а самок 11\%. Размерный ряд самцов 53-113 мм, мода 61-70 мм, средняя ШК 77,4 мм, доля промысловых 34\%. Самки были с ШК 48-92 мм, средняя 66,3 мм. Самки были без икры на плеоподах. Крабы были в межлиночных стадиях 3.

Северная креветка P. borealis eous Makarov, 1935. Северная креветка встречалась в диапазоне 180303 м, однажды отмечена на 98 м. Из 1113 экз. проанализированных креветок самцы составляли 56,6\%, переходные особи (intersex) - 0,6\%, самки - 42,8\%. Длина тела самцов была 31-111 мм с двумя модами 66-70 и 86-90 мм, средняя 82,7 мм. Размер переходных особей был 95-108 мм, в среднем 102,4 мм. Самки были длиной 86-137 мм, средняя - 113,7 мм. Большинство креветок были с неокрепшим панцирем (перелинявшие) 91,8\% и 7,2\% были с твёрдым панцирем. Мгновенная биомасса (запас) северной креветки удовлетворительная (табл. 3).

Виды рода кукумария Cucumaria. В районе НИР доминировала кукумария охотская Cucumaria okhotensis Levin et Stepanov, 2003 на 14-100 м, иногда до 150 м. Максимальные уловы были на двух участках с глубинами 20-40 м. В Камчатско-Курильской подзоне за 30 минут траления уловы были 3000 кг, а в Западно-Камчатской 1800 кг. Масса тела кукумарий колебалась от 42 до 630 г, в среднем 217,9 г. Масса кожно-мускульного мешка (КММ) составляла 26246 г, в среднем 111,8 г. Вес ККМ (выход) от общего веса тела кукумарии был от 19,5 до 84,5\%, в среднем $42,4 \%$. Мгновенная биомасса кукумарии в Камчатско-Курильской подзоне на высоком уровне, а в перспективных районах Западно-Камчатской подзоны достигает 84 тыс. т (табл. 3).

Гибрид краба-стригуна C. bairdi/opilio. Гибрид чаще отмечался в Камчатско-Курильской подзоне (153 экз.). Соотношение полов было 1:0,44. Размерный состав самцов 31-161 мм, средняя ШК 91,3 мм. Самки были с ШК 36-98 мм, а их средняя ШК составляла $76,2 \mathrm{mм.}$

Головоногие моллюски Cephalopoda. В уловах отмечался гигантский осьминог Дофлейна Octopus dofleini (Wülker, 1910) и осьминог песчаный Octopus conispadiceus (Sasaki, 1917). Осьминоги встречались на глубинах 50-300 м. Размер тела 100-250 мм. Эпизодически в уловах были: командорский кальмар Berryteuthis magister (Berry, 1913) на 30-300 м (размер мантии 159-286 мм), гонатус Мадоки Gonatus 
madokai (Kuboera et Okutani, 1977) на 50-100 м (длина мантии 24-96 мм) и тихоокеанская россия (лиловый кальмар-коротышка) Rossia pacifica Berry, 1911 на 50-100 м (длина мантии 60-80 мм).

\section{Состав сообщества непромыслового макрозоо-} бентоса. В районе шельфа Западной Камчатки в траловых уловах идентифицировано 89 видов непромысловых беспозвоночных из 14 систематических групп, для отдельных таксонов даны плотностные характеристики. В Камчатско-Курильской подзоне средняя биомасса макрозообентоса составила 5149,2 кг/км², состав 88 видов, относящихся к 14 таксономическим группам (табл. 4). Биомасса голотурии (C. ochotensis) составила $72 \%$, морские звезды - $18 \%$, офиуры $-4 \%$, морские ежи - $3 \%$, остальные группы составляли $\leqslant 1 \%$ от средней биомассы макрозообентоса. Необходимо отметить резкое падение биомассы и плотности поселения брюхоногих моллюсков сем. Buccinidae в Камчатско-Курильской подзоне по сравнению со среднемноголетними наблюдениями. В траловых уловах зафиксировано несколько живых букцинид различных родов и видов. Большинство моллюсков были умершими с различными стадиями разложения внутренних органов и тканей.

В Западно-Камчатской подзоне средняя биомасса непромыслового тралового макрозообентоса составила 3627 кг/км², идентифицировано 75 видов из 13 таксономических групп (табл. 4). Основу уловов составляли голотурии рода Cucumaria $42 \%$ от общей средней биомассы прилова, морские звезды - $22 \%$, губки - $25 \%$ и офиуры - $3 \%$. В отличие от прошлых лет доля биомассы морских ежей была менее $1 \%$, как и доля остальных бентосных групп.

\section{Состав и структура сообществ донного ихтиоце-} на. В уловах отмечено 104 вида рыб из 25 семейств. Доминировали виды 6 семейств: рогатковые Cottidae 19 видов, бельдюговые Zoarcidae - 14, камбаловые Pleuronectidae - 11, стихеевые Stichaeidae - 7, лисичковые Agonidae и липаровые Liparidae - по 9 видов. Другие семейства были представлены 1-3 видами. Средний улов в пересчете на часовое траление (CPUE) в районе НИР составил 1841 кг. Около 73\% от общего вылова составили: минтай Gadus chalcogramma Pallas, 1814 (54,5\%), камбала сахалинская Limanda

Таблица 4. Биологические характеристики массовых групп непромысловых беспозвоночных на шельфе Западной Камчатки в 2021 г.

Table 4. Biological characteristics of mass groups of non-commercial invertebrates on the shelf of Western Kamchatka in 2021

\begin{tabular}{|c|c|c|c|c|c|c|c|c|c|c|c|c|c|}
\hline \multicolumn{2}{|l|}{ Параметр } & \multirow{2}{*}{$\begin{array}{l}\text { Porifera } \\
15-303\end{array}$} & \multirow{2}{*}{$\begin{array}{l}\text { Actiniaria } \\
20-303\end{array}$} & \multirow{2}{*}{$\begin{array}{c}\text { Alcyonacea } \\
15-100 \\
\end{array}$} & \multirow{2}{*}{$\begin{array}{c}\begin{array}{c}\text { Penna- } \\
\text { tulacea }\end{array} \\
100-200\end{array}$} & \multirow{2}{*}{$\begin{array}{c}\text { Gastropoda } \\
15-303 \\
\end{array}$} & \multirow{2}{*}{$\begin{array}{l}\text { Bivalvia } \\
15-303 \\
\end{array}$} & \multirow{2}{*}{$\begin{array}{c}\begin{array}{c}\text { Crustacea нe- } \\
\text { пром-вые }\end{array} \\
15-303 \\
\end{array}$} & \multirow{2}{*}{$\begin{array}{c}\text { Asteroidea } \\
15-303 \\
\end{array}$} & \multirow{2}{*}{$\begin{array}{c}\text { Ophiuroidea } \\
20-200\end{array}$} & \multirow{2}{*}{$\begin{array}{c}\text { Echinoidea } \\
15-279\end{array}$} & \multirow{2}{*}{$\begin{array}{c}\begin{array}{c}\text { Holothuroidea } \\
\text { (Cucumaria sp) }\end{array} \\
15-150\end{array}$} & \multirow{2}{*}{$\begin{array}{c}\text { Ascidiacea } \\
15-10\end{array}$} \\
\hline Глубина, м ${ }^{1}$ & От-до & & & & & & & & & & & & \\
\hline Нм с Мах уловом & & $45^{*} / 59^{* *}$ & $25 / 101$ & $57 / 16$ & $200 / 200$ & $26 / 40$ & $29 / 20$ & $85 / 105$ & $47 / 129$ & $80 / 50$ & $80 / 103$ & $36 / 25$ & $20 / 16$ \\
\hline \multirow{2}{*}{ Улов, кг } & Max & $62,4 / 907,4$ & $27,3 / 4,2$ & $0,252 / 1,643$ & $10 / 59$ & $9,1 / 30,64$ & $0,58 / 1,30$ & $11,57 / 31,22$ & $1348,5 / 453,6$ & $171,75 / 100$ & $128,4 / 0,268$ & $3000 / 800$ & $10,92 / 13,74$ \\
\hline & Med & $1,91 / 12,8$ & $0,65 / 0,4$ & $0,005 / 0,03$ & $0,17 / 1,16$ & $0,45 / 2,32$ & $0,04 / 0,12$ & $1,3 / 2,1$ & $32,09 / 32,4$ & $5,26 / 1,4$ & $3,87 / 0,014$ & $55,4 / 65,2$ & $0,267 / 0,93$ \\
\hline \multirow[t]{2}{*}{ Биомасса, кг/км² } & Max & $\begin{array}{l}1753,5 / \\
23555,4\end{array}$ & $\begin{array}{c}1105,4 / \\
97,7\end{array}$ & $\begin{array}{c}10,6 / \\
51,1\end{array}$ & $\begin{array}{l}249,9 / \\
1474,7\end{array}$ & $\begin{array}{l}341,5 / \\
795,4\end{array}$ & $\begin{array}{c}26 / \\
35,03\end{array}$ & $\begin{array}{l}401,7 / \\
752,5\end{array}$ & $\begin{array}{c}33706,16 / \\
10203\end{array}$ & $\begin{array}{l}5061,5 / \\
2499,5\end{array}$ & $\begin{array}{c}5415,8 / \\
5,97\end{array}$ & $\begin{array}{c}224957,6 / \\
43384,7\end{array}$ & $\begin{array}{c}272,94 / \\
356,7\end{array}$ \\
\hline & Med & $58,4 / 898$ & $21,8 / 2,56$ & $2,4 / 1,05$ & $4,1 / 29,2$ & $14,33 / 58,8$ & $1,63 / 3,1$ & $44 / 54,4$ & $931,3 / 797,6$ & $181,8 / 100,8$ & $1723 / 0,22$ & $3696,4 / 1657,7$ & $7,6 / 24,01$ \\
\hline \multirow{2}{*}{$\begin{array}{l}\text { Плотность, } \\
\text { эКз./Км² }\end{array}$} & Max & $\begin{array}{l}3768 / \\
13082\end{array}$ & $\begin{array}{c}20692 / \\
465 \\
\end{array}$ & $\begin{array}{l}211 / \\
311 \\
\end{array}$ & $\begin{array}{r}833 / \\
574 \\
\end{array}$ & $\begin{array}{l}176 / \\
3815\end{array}$ & $\begin{array}{c}176 / \\
232,7\end{array}$ & $\begin{array}{c}128441 / \\
14864 \\
\end{array}$ & $\begin{array}{c}358646 / \\
19021 \\
\end{array}$ & $\begin{array}{c}13497 / \\
8998 \\
\end{array}$ & $\begin{array}{c}183228 / \\
31,5\end{array}$ & $\begin{array}{c}899830 / \\
40711 \\
\end{array}$ & $\begin{array}{l}375 / \\
675\end{array}$ \\
\hline & Med & $70 / 979,2$ & $27,1 / 12$ & $8 / 7$ & $17 / 119$ & $13 / 295,7$ & $13 / 18,5$ & $5201 / 1763$ & $6983 / 1633$ & $677 / 297$ & $4904 / 62,5$ & $22864 / 10719$ & $10 / 59,39$ \\
\hline \multicolumn{2}{|l|}{ Доля в уловах, \% } & $1 / 25$ & $\geqslant 1 / \geqslant 1$ & $\geqslant 1 / 1$ & $\geqslant 1 / 1$ & $\geqslant 1 / 1$ & $\geqslant 1 / \geqslant 1$ & $1 / 1$ & $18 / 22$ & $4 / 3$ & $3 / \geqslant 1$ & $72 / 46$ & $\geqslant 1 / 1$ \\
\hline \multicolumn{2}{|l|}{ Кф.встречаемости } & $0,1 / 0,66$ & $0,1 / 0,09$ & $0,09 / 0,03$ & $0,02 / 0,03$ & $0,3 / 0,56$ & $0,2 / 0,29$ & $0,8 / 0,86$ & $0,8 / 0,96$ & $0,2 / 0,156$ & $0,35 / 0,07$ & $0,47 / 0,13$ & $0,12 / 0,31$ \\
\hline \multicolumn{2}{|l|}{ Количество видов } & $6 / 7$ & $3 / 4$ & $1 / 2$ & $1 / 1$ & $21 / 19$ & $8 / 10$ & $14 / 13$ & $13 / 9$ & $1 / 2$ & $2 / 2$ & $5 / 4$ & $4 / 3$ \\
\hline \multicolumn{2}{|c|}{$\begin{array}{l}\text { Доминирующие виды } \\
\text { в Камчатско-Курильской } \\
\text { подзоне }\end{array}$} & $\begin{array}{l}\text { Suberites } \\
\text { sp. }\end{array}$ & $\begin{array}{l}\text { Actinostola } \\
\text { sp. }\end{array}$ & $\begin{array}{l}\text { Gersemia } \\
\text { rubriformis }\end{array}$ & $\begin{array}{l}\text { Halipteris } \\
\text { finmarchika }\end{array}$ & $\begin{array}{l}\text { Clinopegma } \\
\text { chikaoi }\end{array}$ & $\begin{array}{l}\text { Panomya } \\
\text { norvegica }\end{array}$ & $\begin{array}{l}\text { Pandalus } \\
\text { goniurus; } \\
\text { Argis lar; Hyas } \\
\text { coarctatus }\end{array}$ & $\begin{array}{l}\text { Evasterias } \\
\text { echinosoma; } \\
\text { Asterias } \\
\text { rathbuni; } \\
\text { Lethasterias } \\
\text { nanimensis }\end{array}$ & $\begin{array}{l}\text { Gorgonocephalus } \\
\text { eucnemis }\end{array}$ & $\begin{array}{l}\text { Strongylocentrothus } \\
\text { pallidus }\end{array}$ & $\begin{array}{l}\text { Cucumaria } \\
\text { okhotensis }\end{array}$ & $\begin{array}{l}\text { Aplidiop- } \\
\text { sis sp }\end{array}$ \\
\hline \multicolumn{2}{|c|}{$\begin{array}{l}\text { Доминирующие виды } \\
\text { в Западно-Камчатской } \\
\text { подзоне }\end{array}$} & $\begin{array}{l}\text { Suberites } \\
\text { sp. }\end{array}$ & $\begin{array}{l}\text { Actinostola } \\
\text { sp. }\end{array}$ & $\begin{array}{l}\text { Gersemia } \\
\text { rubriformis }\end{array}$ & $\begin{array}{l}\text { Halipteris } \\
\text { finmarchika }\end{array}$ & $\begin{array}{l}\text { Neptunea } \\
\text { beringiana; } \\
\text { Neptunea } \\
\text { ventricosa }\end{array}$ & $\begin{array}{l}\text { Serripes } \\
\text { groenlandicus; } \\
\text { Mya truncata }\end{array}$ & $\begin{array}{l}\text { Pandalus } \\
\text { goniurus; } \\
\text { Pagurus } \\
\text { rathbuni; } \\
\text { Telmessus } \\
\text { cheiragonus }\end{array}$ & $\begin{array}{l}\text { Evasterias } \\
\text { echinosoma; } \\
\text { Lethasterias } \\
\text { nanimensis; } \\
\text { Ctenodiscus } \\
\text { crispatus }\end{array}$ & $\begin{array}{l}\text { Gorgonocephalus } \\
\text { eucnemis }\end{array}$ & $\begin{array}{l}\text { Strongylocentrothus } \\
\text { pallidus }\end{array}$ & $\begin{array}{l}\text { Cucumaria } \\
\text { okhotensis }\end{array}$ & $\begin{array}{l}\text { Syncarpa } \\
\text { oviformis }\end{array}$ \\
\hline
\end{tabular}

Примечание: ${ }^{1}$ - диапазон глубины встречаемости животных для всего обследованного шельфа Западной Камчатки в период НИР; ${ }^{-}$- параметр для Камчатско-Курильской подзоны; /** - через дробь параметр для Западно-Камчатской подзоны. 
sakhalinensis Hubbs, 1915 (7,2\%), керчак многоиглый Myoxocephalus polyacanthocephalus Pallas, 1814 (5,5\%) и камбала желтопёрая Limanda aspera Pallas, 1814 $(5,4 \%)$. Среди донных и придонных рыб по сравнению с прошлым годом рост CPUE отмечен у многоиглого керчака, сем. Liparidae, белокорого палтуса Hippoglossus stenolepis Schmidt, 1904, у камбал двухлинейной Lepidopsetta polyxystra Orr et Matarese, 2000 и хоботной Limanda proboscidea Gilbert, 1896. В целом, средние значения CPUE снизились у многих донных и придонных рыб как по сравнению с прошлым годом, так и относительно среднемноголетнего уровня. Уловы пелагических рыб также были ниже, чем в прошлые годы, тем не менее CPUE минтая по-прежнему превышал среднемноголетнее значение.

\section{Благодарности}

Авторы выражают искреннюю признательность экипажу НИС «Дмитрий Песков» за помощь в сборе научной информации.

\section{ЛИТЕРАТУРА}

Бизиков В.А., Гончаров С.М., Поляков А.В. 2006. Новая географическая информационная система «Картмастер» для обработки данных биоресурсных съёмок // VII Bсеросс. Конфер. пром. беспозв. М.: Изд-во ВНИРО. С. 18-24.

Моисеев С.И., Буяновский А.И., Моисеева С.А. 2018. Определение широкопалости у крабов-стригунов рода Chionoecetes в полевых условиях // Труды ВНИРО. Т. 172. C. 6-26.

Родин В.Е., Слизкин А.Г., Мясоедов В.И., Барсуков В.Н., Мирошников В.В., Згуровский К.А., Канарская О.А., Федосеев В.Я. 1979. Руководство по изучению десятиногих ракообразных Decapoda дальневосточных морей. Владивосток: Изд-во ТИНРО. 59 с.

\section{REFERENCES}

Bizikov V.A., Goncharov S.M., Polyakov A.V. 2006. GIS «Chartmaster» - new geographic information system for processing the data of hydrological surveys // VII AllRussian. konf. commers. invertebrate. Moscow: VNIRO Press. P. 18-24.

Moiseev S.I., Buyanovsky A.I, Moiseeva S.A. 2018. Determination of the terminal molt of the snow and tanner crabs in the field // Trudy VNIRO. Vol. 172. P. 6-26.

Rodin V.E., Slizkin A.G., Myasoedov V.I., Barsukov V.N., Miroshnikov V. V., Zgurovsky K.A., Kanarskaya O.A., Fedoseev V. Ya. 1979. A guide to the study of ten - legged crayfish crustaceans Decapoda of the Far Eastern Seas. Vladivostok: TINRO Press. 59 p.

Поступила в редакцию 18.11.2021 2. 